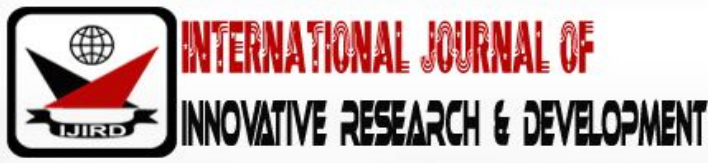

ISSN 2278 - 0211 (Online)

\section{Identified Effective Events and Activities of SBTD Programs in Sri Lanka}

\author{
Dr. Senevirathna Bandara \\ Senior Lecturer, Department of Humanities, Rajarata University of Sri Lanka, Mihintale, Sri Lanka
}

\begin{abstract}
:
Professional development is an essential component in all professions and professional development leads to improve quality of outcomes in all professions. Teaching is a well-recognized profession and teacher professional development programs helps to enhance quality of students' outcomes. Two Teacher development programs are could be found in Sri Lanka, these are School Based Teacher Development (SBTD) and Non School Based Teacher Development programs. School Based Teacher Development (SBTD) programs are planned, organized and implemented by the principal and staff of the school, other programs are planned, organized and implemented by different outside organizations of the school. Various types of events and activities are followed in these teacher development programs, this research seeks effective events and activities which used in SBTD programs in selected secondary schools in Sri Lanka. Qualitative research method has been employed and the research design was framed within a case study approach. Very important events and activities were recognized and finally, the conclusions and recommendations were developed from the findings.
\end{abstract}

Keywords: Professional development, school based teacher development, secondary schools, school-based management

\section{Introduction}

There are many teacher professional development programs are used in secondary schools in Sri Lanka and all over the World, Among these teacher professional development programs, School-Based Teacher Professional Development (SBTD) are very important, because they allows teachers to plan, organize and implement their own professional development programs, considering their particular needs, as well as those of students and school. School-Based Management (SBM) is a new concept for Sri Lanka and it was introduced in the late 1990s to the Sri Lankan education system. Through the SchoolBased Management (SBM) concept the power and authority were decentralized from central government to particular individual schools. Therefore, since the last decade principals and staff have had the opportunity to plan, organize and implement their own teacher professional development a school-based system (Bandara, 2010).

This study focuses on investigate and identify effective events and activities which are applied in School-Based Teacher Development (SBTD) programs in secondary schools in Sri Lanka.

\section{Literature Review}

Professional development for teachers is a key mechanism for improving classroom instruction and student achievement (Cohen \& Hill, 2000). Nowadays, teachers' roles have become complicated and broader in scope. Greenwood and Gaunt (1994) compares a teacher of a class to a chief executive, needing both to understand the 'business' throughout and the socio-political environment in which it operates, and to be able to help people (the students) to carry out their work effectively. Further, they have to work with children not only collectively, perhaps when explaining a goal or delivering information, but also individually, making judgments about how best to help each student on the basis of their subject knowledge and their knowledge of a students' needs. Under such a situation, teachers should be given the opportunities to update their knowledge, skills and attitudes, because we are in a new era of teaching which is increasingly complex and demanding (Fullan, 1995; Hargreaves, 1997).

Butler (1992b) believes that effective teacher development programs have three types of learning situations, and these are mentioned as function, process and product. Function is explained as using knowledge for learning, process is about what happens when people learn, and product is described as how participants in effective programs develop new knowledge and skills as teachers. Therefore, well designed, thoughtfully planned and adequately supported professional development is an essential component and an ingredient in the process of teacher professional development (Good et al., 2003; Christine, 2006). This means that teacher professional development programs should be well planned rather than poorly organized or 
'ad-hoc'. "Many studies have identified teachers as the essential ingredient of any plan designed to improve students' outcomes, school effectiveness and the quality of education" (Cumming \& Owen, 2001, p. 5). According to this idea, Professional Development programs for teachers are important because, professional development is highly prominent in the field of teacher development. Cumming and Owen, (2001) further explained about teacher empowerment, collaborate-action and strategic partnerships in teacher professional development.

\section{Methodology}

The overarching research question for this study is: What are the more effective events and activities in SBTD programs in secondary schools in Sri Lanka?

The following four sub-questions are used to support this overarching research question.

- What types of events and activities are used in SBTD programs in Sri Lanka?

- How is the effectiveness of events and activities in SBTD programs demonstrated in each school?

- What specific changes in teacher practice followed events and activities in SBTD programs?

To seek answers for the research questions, a qualitative research method has been employed and the research design was framed within an interpretive and case study approach. Furthermore, the data collection process employed in-depth interviews which were conducted with ten principals who were chosen from a sample of secondary schools, non-participant observation, and searching of documents of the above schools. Moreover, the Activity theory was used for the data analysis and interpretation of the research findings. Finally, the conclusions and recommendations were developed from the data.

The sample for the case study is ten selected secondary schools, therefore the participants for the study were above ten secondary school principals who have considerable experience and qualifications from three administrative districts selected in this study. Five were male and five were female participants. The samples of school included were girls, boys and mixed schools. In data analysis process, four codes have been developed and each code includes several sub-codes. "Any number of possible codes may be used and the coding categories become specific to the research study" (Wiersma \& Jurs, 2005, p. 207). In this investigation, the triangulation method was used to develop the validity of the result. Rothe (2000, p. 23) explains Triangulation as "search, by using several different bearings from different directions".

\section{Ethical Consideration}

In this investigation, ethical procedures of research were followed. Ethics application for the study was approved by the Human Research Advisory Group of Faculty of Arts and Education of Deakin University in Australia. In this case study, ten principals were interviewed and throughout the interviews proper ethical conducts were observed and taken into consideration. Finally, during data analyzing and interpretation, follow-up or debriefing of the ethics consideration was also considered. For instance, personal or schools' names were not mentioned in any written documents, but pseudonyms or coded symbols were used in documents.

\section{Findings of the Research}

The findings of the study shows different types of events and activities were used in SBTD programs in secondary schools in Sri Lanka. workshops, seminars, discussion and lectures, Field-trips, SBTD programs in out-side locations, Staff meetings, Morning Assembly, Mentoring programs, Teachers' notice-board, Research Programs-Action Research, Publications, Newsletters, Conferences, Exhibitions, Supervisions, Model teaching, induction programs for Newly Qualified Teachers (NQTs), team teaching, peer learning etc. In addition, some particular events (teachers' corner, attitudes development programs, etc.) were identified in this study. These innovative SBTD programs included a range of different events that overlapped and interacted. As a result, these programs contribute broadly to the effectiveness of teachers' personal and professional development (findings shows that teachers have multiple opportunities to develop their practices in this context). The literature of teacher professional development articulates aspects of teacher development programs, some are traditional and some are continuing, long-term activities, the findings of the study could be compared with the references of the literature. Table: 1 shows identified traditional and continuing, long-term activities of the study of SBTD programs in Sri Lanka.

\begin{tabular}{|c|c|c|c|}
\hline & Group of Activity & Identified Activities & Nature of the Activities \\
\hline 1 & $\begin{array}{c}\text { Traditional activities } \\
\text { (Smith \& Gillespie, 2007; Yates, 2007; Suzanne et al., 1999) }\end{array}$ & $\begin{array}{l}\text { Seminars, workshops, } \\
\text { conferences }\end{array}$ & $\begin{array}{c}\text { Teacher-centred } \\
\text { lecturing }\end{array}$ \\
\hline 2 & $\begin{array}{c}\text { Continuing, long-term activities } \\
\text { (Smith \& Gillespie, 2007; Smith et al., 2003; Lalitha, 2005) }\end{array}$ & $\begin{array}{l}\text { Action research, SBTD } \\
\text { programs at outside } \\
\text { locations, model school } \\
\text { visits, staff meetings, } \\
\text { induction programs for } \\
\text { NQTs, team teaching, } \\
\text { mentoring }\end{array}$ & $\begin{array}{l}\text { Discussion, group work, } \\
\text { self-learning, project } \\
\text { report, study circles }\end{array}$ \\
\hline
\end{tabular}

Table: 1. Identified Traditional and Continuing, Long-Term Activities of the Study 
The findings of the study recognized different types of events and activities which were used in SBTD programs in secondary schools in Sri Lanka, among them effective and innovative events and activities are can be used effectively in SBTD programs in secondary schools in Sri Lankan context.

\section{Conclusion}

This study based on SBTD programs in secondary schools in Sri Lanka, through the qualitative research approach value and significant data were collected. Analyzing the collected data different types of events and activities were identified, the literature referred some events and activities are traditional activities these are commonly used in various SBTD and other teacher professional development programs in secondary schools in the country. However the findings of the study shows innovative and continuing, long-term activities were applied some secondary schools in Sri Lanka, these effective events and activities could be used in SBTD programs in secondary school context in Sri Lanka.

\section{References}

i. Bandara, B.M.S. (2010). School-based Teacher Development Programs in Sri Lanka, PhD thesis, Deakin University, Melbourne Butler, J. A. (1992). Staff Development. NW Archives Regional Educational Laboratory. http:/ / www.nwrel.org/ scpd/ sirs/ 6/ cu12.html

ii. Christine, L. (2006). Reality Check: Survey Highlights the Disparity between the Ideal and Real in Professional Learning Programs. Journel of Staff Development, v 27, p 61-64

iii. Cohen, D. K., \& Hill, H. C. (1998). Instructional policy and classroom performance: The mathematics reform in California (CPRE Research Report Series, RR-39).Philadelphia: University of Pennsylvania, Consortium for Policy Research in Education

iv. Cumming, J. \& Owen, C. (2001). Reforming Schools Through Innovative Teaching.Canberra, Australian College of Education

v. Fullan, M. (1995). The Limits and the Potential of Professional Development.Burkingham, Open University Press

vi. Good, J., M, Weaver \& Andrew (2003). Creating learning communities to meet teachers' need in professional development. Journel of In-service Education, Volume 29 Number 3 pp. 439-450 (12)

vii. Greenwood, M. S. \& Gaunt, H., J (1994). Total Quality Management for Schools.Cassell, London,

viii. Hargreaves, A. (1997). From Reform to Renewal: A New Deal for a New Age.Buckingham, Open University Press

ix. Lalitha, H. D. A. (2005). Development of a Model for the Continuing Professional Development of Teachers: A Qualitative Investigation. University of Wollongong. Doctor of Education

x. Smith, C., Hofer, J., Gillespie, M., Solomon, M. \& Rowe, K. (2003). How Teachers Change: A study of Professional Development in Adult Education. National Center for the Study of Adult Learning and Literacy. Cambrige.

xi. Smith, C. \& Gillespie, M. (2007). Research on Professional Development and Teacher Change: Implications for Adult Basic Education.

xii. Suzanne, M., Wilson \& Berne, J. (1999). Teacher Learning and the Acquisition of Professional Knowledge: An Examination of Research on Contemporary Professional Development. Review of Research in Education, Vol. 24 (1999), 173-209

xiii. Rothe, P.J. (2000). Understanding Qualitative Research.Albera, Canada Council for the Arts

xiv. Wiersma, W. \& Jurs, S. G. (2005). Research Methods In Education an introduction.Boston, Allyn \& Bacon

xv. Yates, S. M. (2007). Teachers' perceptions of their professional learning activities. International Education Journal, Vol. 8 (2), pp. 213-221 